\title{
EFFECTIVENESS OF E-COMMERCE IN INDIA
}

\author{
Dr. Bhakti D. Mehta \\ Working as Assistant professor, Nava Samaj Mandaldegree College, Vile Parle (East) Mumbai400057
}

\begin{abstract}
E-commerce business represents electronic trade. E-commerce includes an online exchange. Online business gives numerous advantages to the shoppers in type of accessibility of products at lower cost, wider choices and saves time. Online business manages selling and buying of labour and products with the help of internet and computer networks. This paper endeavours to feature the various difficulties looked by the E-trade in India, comprehend the fundamental development factors needed for E-business, express the prosperity in India and retail E-Commerce deals in India. The investigation discovered that, in the area of E-business, the presence of the wholesalers is at the most serious danger on the grounds that the maker can without much of a stretch disregard them and offer their items to the retailers and the buyers. Wholesalers can exploit E-trade in building up agreements with reputed producers and connecting their business with the on the online facility. The investigation additionally discovered that, E-commerce gives the different sorts of freedoms to the wholesalers, retailers, makers and the People.
\end{abstract}

Keywords: E-commerce, Challenges, On Line Shopping, Evolution, Prosperity.

\section{INTRODUCTION}

Online business represents electronic trade. Managing in products and services through the electronic media and internet is called as E-trade. Online business identifies with the site of the seller, who sells items or administrations straight forwardly to the client from the gateway utilizing a computerized shopping basket or advanced shopping bin framework and permits payment through credit card, debit card or electronic fund transfer payments. Internet business is the development of business onto the World Wide Web (WWW). Internet business works with new sorts of data based business measures for coming to and cooperating with clients and also decrease costs in overseeing orders and collaborating with a wide scope of providers and exchanging accomplices. For agricultural nations like India, ECommerce offers significant opportunities.

Electronic trade related to a wide scope of online business undertaking for goods and services. Today E-trade in Indian culture has turned into an inseparable part of regular daily existence. Availability of to E-trade stages isn't an advantage yet rather a need of everyone, especially in the metropolitan cities. Today the prompts a huge development in the Ebusiness space, with an expanding number of clients entering on E-trade sites and buying items using cell phones. India is in an excellent situation for the development and advancement of the E-business area.

\section{AIMS \& OBJECTIVES}

1. To investigate the current trends of E-business in India.

2. To review the different difficulties faced by E-business players in India.

3. To review the possibilities of E-business in India.

4. To recognize the current status and patterns of E-Commerce.

\section{RESEARCH METHODOLOGY}

This research work depends on information which are gathered from a few sources for example research papers, research articles, diaries, books, sites, paper, reports and so forth.

\section{REVIEW OF LITERATURE}

\section{Dr. Anukrati Sharma (2013)}

The article entitled "A study on E-commerce and Online Shopping: Issues and Influences". In this article an attempt is made to study the recent trends, influences, preferences of customers towards E-commerce and onlineshopping and to give the suggestions for the improvement in online shopping websites. The study found that, most of the people who are engaged in making the decision of purchasing are in the age of 21-30 years. While making the websites for online shopping it must be designed in a very planned and strategic way. 
2. Nisha Chanana and Sangeeta Goele (2012)

The article entitled "Future of E-commerce in India". In this article an attempt is made to study the overview of the future of E-commerce in India and discusses the future growth segments in India's of E-commerce. The study found that, various factors that were essential for future growth of Indian E-commerce. The study also found that, the overall E-commerce will increase exponentially in coming years in the emerging market of India.

\section{CONCEPT OF E-COMMERCE IN INDIA}

\section{1) Multi Product E-Commerce:}

Some internet portals give practically all classifications of products and services in a one website; they are focusing on clients of each conceivable products and services. Indian E-Commerce entrances give labour and products in an assortment of classes like attire and accessories for people, health and beauty products, books and magazines, PCs and peripherals, vehicles, collectibles, programming, customer gadgets, domestic devices, jewellery, audio/video entertainment goods, gift articles, land and administrations, business and openings, work, travel tickets, marriage and so on Models: www.indiayplaza.com, www.thebestofindia.com, www.khoj.com, www.sify.com, www.rediff.com, www.indiatimes.com and so forth.

\section{2) Single Product E-Commerce:}

Some Indian portals/sites bargain in a particular field. Models:

- In cars, the entries are http://www.indiacar.com and http://www.automatindia.com, on these destinations we can purchase and sell four wheelers and bikes new just as old vehicles on the web. A portion of the administrations they give are vehicle exploration and surveys, online assessment, specialized details, vehicle protection, vehicle finance, vendor finder and so forth.

- In stock and offers displays on the areas are http://www.equitymaster.com, http://www.5paisa.com. A portion of the administrations presented to enlisted individuals are internet purchasing or managing of stocks and offer, market examination and exploration, organization data, correlation of organizations, research on value and common assets, following business area designs.

- In land, the gateways like http://www.indiaproperties.com. This site work with internet managing in land, they offer out and out buy or rent of a property through their entryway. They give data on new properties just as for resale. A portion of the partnered administrations are lodging finance, insurance agencies' engineers and inside creators, property the executives advisor administrations and so on

- In travel and the tourism industry a significant legislature of India portal is http://www.tourismindia.com. The vacationer location locales are ordered by the topics like eco-subjects relates to wildernesses, flora \& fauna, sea shores of India, engineering attractions, fortifications and spots, slope resorts, experience traveling, hiking and so on Different administrations offered are identification and visa, travel and convenience data, climate data, celebration and reasonable dates, shopping, visit administrators and so on There are different locales like http://www.incredibleindia.org, it feature the traveler objections of a particular area in India, which covers North East India.

- In instance of marriage, marriage entry like http://www.jeevansathi.com and http://www.saadi.com. On these sites one can look for a reasonable match by locale of home, religion or cast. Once enrolled with these entrances, they have email office and visit rooms, so two or three becomes acquainted with additional with regards to one another prior to settling on the choice of their lives.

- In instance of work, two significant portals like www.monsterindia.com and www.naukri.com are instrumental in giving position searchers reasonable business office. The help for work searchers is free and for business they charge an ostensible expense. Occupations are accessible online in fields, going from secretarial to programming improvement and from land to training.

\section{TYPES OF E-COMMERCE}

\section{- Business to Business (B2B):}

A B2B model of business includes the lead of exchange between a minimum of two organizations/organizations. The channels of such exchange for the most part incorporate customary wholesalers and makers who are managing retailers.

- Business to Consumer (B2C):

Business-to-Consumer model of business manages the retail parts of online business, for example the offer of items as well as services to the top customer through advanced means. It empowers the purchaser to have a definite gander at their proposed obtainments prior to submitting a request. After the area of such orders, the organization/specialist getting the request will then, at that point, convey a comparable to the purchaser during a helpful time frame. A portion of the organizations working in this channel incorporate notable players like Amazon, Flipcart, and so forth. 


\title{
- Consumer to Consumer (C2C):
}

This plan of action is utilized by a buyer for selling utilized merchandise and additionally administrations to different purchasers through the computerized medium. The agreement here takes via third party, which include OLX, Quickr, etc. - Consumer to Business (C2B):

The $\mathrm{C} 2 \mathrm{~B}$ model gives the end shoppers a chance to sell their items/administrations to organizations. The strategy is well known in publicly supporting based undertakings, the idea of which ordinarily incorporates logo planning, offer of sovereignty free photos/media/plan components, etc.

\section{FUNCTIONS OF E-COMMERCE}

1) Communication function - delivery of information and/or documents to facilitate business transactions. Example: E-Mail.

2) Process management function - covers the computerization and enhancements of business measures. Example: networking two computers together.

3) Service management function utilization of technology to work on the nature of service. Example: Federal Express website to track shipments and schedule., we fast .

4) Exchange capacities - provides the capacity to purchase/sell on the internet or another web-based services. Example: Amazon.com.

\section{CHALLENGES OF E-COMMERCE EXTERNAL CHALLENGES:}

\begin{abstract}
- Product and Market Strategy:
Internet business organizations need to resolve issues relating to quickly developing client sections and item portfolios access data on market knowledge on development, size and offer deal with different client commitment stages center around venture into new geologies, brands and items and at the same time tackle a hypercompetitive estimating climate. - Customer and Digital Experience:

Organizations need to give a rich, new and basic client experience not equipped towards revelation, oversee conflicting brand insight across stages; oversee expansion of advancements; and handle time to showcase tension for new applications. In the new past, online media has become more powerful than paid showcasing.

- Payments and Transactions:

Internet business organizations might confront issues around security and protection break and controlling invented exchanges. Further, RBI limitations for prepaid instruments or E-Wallets go about as obstructions. According to an exchanges viewpoint cross boundary charge and administrative issues and backend administration duty and retaining assessment can have genuine ramifications.

\section{- Fulfillment:}

Organizations should check if the actual foundation gets influenced by the web speed. Likewise the absence of a coordinated start to finish coordinations stage and advancement centered satisfaction choice could cause conveyance issues. Difficulties around invert coordinations the board and outsider coordinations associations could likewise go about as hindrances to development.
\end{abstract}

\section{INNER CHALLENGES:}

\footnotetext{
- Organization Scaling:

Internet business organizations should ensure association configuration stays up with the quickly advancing business system, alongside liquid administration, solid authority and the executives improvement. According to a development viewpoint, distinguishing obtaining openings, raising money and IPO preparation becomes important. According to an innovation viewpoint, change IT as a development center point and address the absence of collaboration between business, innovation and tasks elements of the undertaking.

- Tax and Regulatory Structuring:

Organizations should resolve issues around imperfect stockroom charge arranging awkwardness between FDI standards opposite satisfactory element controls, wasteful holding IPR or element construction and global expense failures.

- Risk Fraud and Cyber Security

According to a danger viewpoint E-trade organizations could confront issues around brand hazard, insider dangers and site uptime. Issues around worker seller nexus, pay off and defilement make organizations powerless against fines. Network safety likewise raises a few worries around site abuse by outer substances.

- Compliance Framework:

Web based business organizations need to conform to a few laws, large numbers of which are as yet developing. Likely issues around digital law consistence, wasteful enemy of debasement system, lawful openness in arrangements or plans, aberrant and direct duty consistence structure and rules and guidelines could present issues.
} 


\section{FINDINGS OF THE STUDY}

In the world of E-commerce, the existence of the wholesalers is at the greatest risk because the producer can easily ignore them and sell their products to the retailers and the consumers. Wholesalers can benefits of E-trade in setting up agreements with presumed makers and connecting their business on online. The retailer can save his existence by linking his business with the online distribution. The retailer can give extra data about different things to the purchasers, meet electronic orders and be in contact with the shoppers constantly. Therefore, E-commerce is a good opportunity.

Manufactures can take the benefits of E-trade by connecting themselves with internet, by giving data about their items to different connections in the business chain and by having a brand character. Individuals know about the accessibility of different items in the business sectors through the assistance of TV, paper, site and so forth the accessibility of another item and its cost and different provisions can be known without any problem.

\section{SUGGESTIONS:}

The amazing impact of different online media instruments like Facebook permits customers to sort out their best things and segments it into them and assortments to share and discuss with other people. With the increment in little and medium undertakings, unfamiliar direct venture, worldwide organizations, making millions new positions, another age of universally disapproved of shoppers. With developing open positions, clients are readily ready to pay for the items on online. The site for internet shopping ought to be in reasonable language. The language ought to be kept straightforward while making the sites.

\section{CONCLUSION:}

Today E business has turned into a vital role of regular day to day existence. Availability to E-business stage isn't an advantage but instead a need for individuals, especially people groups who are remaining in metropolitan regions. Because of quick reception of web empowered gadgets like Smartphone and Tablets, we have seen an unmatched development in E-business. The telecom innovation has totally changed the method of our living, specialized strategies, shopping and so forth It gigantically affects how we speak with companions and family members how we travel, how we access the data and the manner in which we purchase or sell items and administrations. The development of E-trade volumes in India is drawing in the consideration of players around the globe.E-trade sets out new open doors for business, instruction and scholastics. Apparently there is gigantic potential for giving E-business instruction.

With the fast development of web, E-business is set to assume a vital part in the 21 st century, the new chances that will be opened up, will be available to both large corporations and small companies.

\section{REFERENCES}

1) http://data.worldbank.org/indicator/NY.GDP.MKTP.KD.ZG?locations=IN

2) www.iamwire.com

3) www.internetworldstats.com

4) www.tradingeconomics.com

5) www.trai.gov.in 